\title{
The Use of Hydrogen Peroxide for the Digestion and Determination of Total Nitrogen in Chickpea (Cicer arietinum $\mathrm{L}$.) and Pigeonpea (Cajanus cajan $\mathrm{L}$.)
}

\author{
Umaid Singh, Kanwar L. Sahrawat, Ramamurthi Jambunathan \\ and John R. Burford
}

International (rops Research Institute for the Semi-arid Tropics. IC RISAT Patuncheru PO. Andhra Pradesh 502.324. India

(Manuscript received 27 July 198,3)

\begin{abstract}
The use of hydrogen peroxide as an alternative to catalysts in the determination of nitrogen in plant materials has been investigated. Nitrogen determination in leaf, stem and seed samples of chickpea and pigeonpea was carried out by three digestion procedures, using hydrogen peroxide $\left(\mathrm{H}_{2} \mathrm{O}_{2}\right.$ digestion) without a cattalyst, and with mercury or selenium as catalysts (catalyst digestions). The nitrogen values obtained by the three digestion procedures did not differ significantly from each other when examined by microKjeldahl (MKJ) using mercury as a catalyst, and by a Technicon auto analyser (TAA) using selenium as catalyst. The gradual addition of $\mathrm{H}_{2} \mathrm{O}_{2}$, as recommended previously, was found to be unnecessary. In view of the cost and health hazards implicated with the use of mercury and selenium for digestion, the procedure based on $\mathrm{H}_{2} \mathrm{O}_{2}$ digestion is preferable for large scale $\mathrm{N}$ determinations in plant tissue and seed samples of these pulse crops. The results sugest that the $\mathrm{H}_{2} \mathrm{O}_{2}$ digestion technique can be conveniently adapted for total $\mathrm{N}$ analysis in plant tissues and grain samples by either TAA or MKJ method.
\end{abstract}

\section{Introduction}

With the increased demand for $\mathrm{N}$ analyses in samples of plant origin, many attempts have been made to develop rapid and reliable techniques for determining $\mathrm{N}$ in the various parts. Although several rapid methods of $\mathrm{N}$ determination have been established, the use of Kjeldahl digests for the determination of total $\mathrm{N}$ remains a standard practice in many laboratories. Findings from a review on the use of a catalyst in Kjeldahl digestions established mercury as the most effective' and commonly used catalyst in routine laboratory work. The speed and dependability of $\mathrm{N}$ analysis of plant material, including grain samples, have been considerably enhanced with the availability of the Technicon auto-analyser, where selenium is used as a catalyst for digestion. ${ }^{2}$ The procedure using the Technicon auto-analyser (TAA) has been found suitable for large-scale screening of grain from chickpea and pigeonpea. ${ }^{3,4}$

Several studies have been undertaken to find suitable replacements for the poisonous catalysts, mercury and selenium in the analysis of feedstuffs and cereal grains. ${ }^{5,6}$ These workers have suggested titanium dioxide in combination with copper sulphate as an alternative catalyst for the determination of total $\mathrm{N}$ by Kjeldahl procedure. A comparison of mercury and selenium catalysts for the determination of Kjeldahl-nitrogen in leaf and stem tissues of pigeonpea has been reported. ${ }^{7}$ Other workers have found that, with foodstuffs, potassium-copper sulphate used as a catalyst gave better results than mercury. ${ }^{8}$

The digestion of plant tissue with sulphuric acid and $\mathrm{H}_{2} \mathrm{O}_{2}$ followed by direct nesselerisation for total $\mathrm{N}$ determination was thoroughly studied by Yuen. ${ }^{9}$ The determination of total $\mathrm{N}$ in dried plant 
material by digestion with a sulphuric acid- $\mathrm{H}_{2} \mathrm{O}_{2}$ mixture was found to be rapid, and simpler, than the normal Kjeldahl procedure, in which sulphuric acid with addition of potassium sulphate and a catalyst is used. ${ }^{11}$ The sulphuric acid- $\mathrm{H}_{2} \mathrm{O}_{2}$ digestion method nearly always gave results that were identical with those obtained by the Kjeldahl method. "Florence and Milner found that $\mathrm{N}$ in biological materials can be routinely determined in Kjeldahl digestion using $\mathrm{H}_{2} \mathrm{O}_{2}$." The present authors have evaluated the use of $\mathrm{H}_{2} \mathrm{O}_{2}$ for the digestion and determination of a wide range of $\mathrm{N}$ values in leaf, stem and seed samples of chickpea and pigeonpea. Results from the $\mathrm{H}_{2} \mathrm{O}_{2}$ digestion technique and the mercury and selenium catalyst digestion methods, used as standards, were compared.

\section{Materials and Methods}

\subsection{Plant Material}

Leaf, stem and seed samples of chickpea and pigeonpea were obtained from crops grown under normal agronomic practices during the 1980-81 season at ICRISAT Centre. Pattancheru, near Hyderabad. The samples were oven-dried at $65^{\circ} \mathrm{C}$. Seed samples were ground to pass a 6 ()-mesh screen using a Udy cyclone mill, the leaf and stem samples were ground to a fine powder (4)-60) mesh) using a Pica mill.

\subsection{Apparatus and reagents}

The apparatus used included a $75 \mathrm{ml}$ capacity digestion tube, an electrically heated block digestor (BD-40 Tecator. Sweden) capable of holding 40 tubes (2-3 boiling chips were used per tube), and a technicon auto analyser I (TAA) (Technicon, New York).

The reagents used were $30 \%$ (by vol) AR grade hydrogen peroxide solution (Sarabhai, India); sulphuric and phosphoric acids (AR grade, BDH. England): mercury catalyst: Kjeltab MQ tablet, each containing $1.5 \mathrm{~g} \mathrm{~K}_{2} \mathrm{SO}_{4}$ and $0.075 \mathrm{~g} \mathrm{HgO}$; selenium catalyst: Kjeltab auto-tablet, each containing $1.5 \mathrm{~g} \mathrm{~K}_{2} \mathrm{SO}_{4}$ and $7.5 \mathrm{mg} \mathrm{Se}$. Both catalysts were obtained from Thomson and Capper Lid. Cheshire.

\subsection{Experimental procedures}

\subsubsection{Mercury catalyst digestion}

A 40-50 mg sample was placed in the Kjeldahl digestion flask. One Kjeltab MQ and $3 \mathrm{ml}$ sulphuric acid mixture 95:5 (by vol) conc. sulphuric acid: $85 \%$ phosphoric acid were added for digestion.

\subsubsection{Selenium catalyst digestion}

A 70-80 mg sample was placed in a digestion tube. One Kjeltab auto-tablet was added, followed by $3 \mathrm{ml}$ of the sulphuric-phosphoric acid mixture as above. Digestion was performed at 37()$^{\circ} \mathrm{C}$; after $1 \mathrm{~h}$ the material became clear, indicating complete digestion.

\subsection{3. $\mathrm{H}_{2} \mathrm{O}_{2}$ digestion}

A $70-80 \mathrm{mg}$ sample was placed in a digestion tube with $2-3$ boiling chips, $1.5 \mathrm{~g}$ potassium sulphate and $3 \mathrm{ml}$ sulphuric-phosphoric acid mixture added. The $\mathrm{H}_{2} \mathrm{O}_{2}$ was then added: $2 \mathrm{ml}$ for leaf and seed samples, and $3 \mathrm{ml}$ for the stem sample. Digestion was performed at 37()$^{\circ} \mathrm{C}$ for $1 \mathrm{~h}$. Although the contents reached the clearing stage after about $40 \mathrm{~min}$ of digestion, heating was continued for $1 \mathrm{~h}$ in order to compare the results with catalyst digestion. After cooling, distilled water was added to the digest to $75 \mathrm{ml}$, and aliquots were taken for the determination of nitrogen. All determinations were carried out in triplicate.

\subsubsection{Total $N$ determination}

Total $\mathrm{N}$ in all the $\mathrm{H}_{2} \mathrm{O}_{2}$ digests were determined by both Technicon auto-analyser (TAA) ${ }^{3}$ and microKjeldahl $(\mathrm{MKJ}) .{ }^{13}$ The catalyst digests prepared by using selenium were analysed by TAA. 
Table 1. Ranges and means of percentage $N$ of leat. stem and seed samples of chickpea and pigeonpea estimated hy $\mathrm{H}_{2} \mathrm{O}_{2}$. mercury and selenium catalyst digestion procedures

\begin{tabular}{|c|c|c|c|}
\hline \multirow[b]{3}{*}{ Tissuc } & \multicolumn{3}{|c|}{ Nitrogen content $(" i)^{u}$} \\
\hline & \multirow[b]{2}{*}{$\mathrm{H}_{2} \mathrm{O}_{2}$ digestion ${ }^{\prime}$} & \multicolumn{2}{|c|}{ Catalyst digestion } \\
\hline & & Mercur! & Selenium" \\
\hline Chickpea: I.caf $(n=4())$ & $\begin{array}{c}2.54-4.43 \\
(3.4(1)\end{array}$ & $\begin{array}{c}2.6 n-4.5 n \\
(3.3 x)\end{array}$ & $\begin{array}{c}2.58-4.50 \\
(3.37)\end{array}$ \\
\hline Stcm $(n=3.5)$ & $\begin{array}{c}(0.6 .3-1.70) \\
(1.18)\end{array}$ & $\begin{array}{c}(1.6 x-1.7 x \\
(1.26)\end{array}$ & $\begin{array}{c}11.63-1.79 \\
(1.21)\end{array}$ \\
\hline Sced $(n=6(x))$ & $\begin{array}{c}3.2(1-4.54) \\
(3.72)\end{array}$ & $\begin{array}{c}3.26-4.57 \\
(3.74)\end{array}$ & $\begin{array}{c}3.2 \times 4.52 \\
(3.73)\end{array}$ \\
\hline Pigconpca: Leaf $(n=4(1)$ & $\begin{array}{c}3 .(1)(-3.26 \\
(3.15)\end{array}$ & $\begin{array}{c}2.8+3.28 \\
(3.14)\end{array}$ & $\begin{array}{c}2.9(1-3.2 x \\
(3.17)\end{array}$ \\
\hline Stem $(n=35)$ & $\begin{array}{c}0.7 x-1.16 \\
(11.89)\end{array}$ & $\begin{array}{c}11.74-1.211 \\
(11.94)\end{array}$ & $\begin{array}{l}11.5(1) 1.17 \\
\text { (1). } 91)\end{array}$ \\
\hline Seced $(n=6(1))$ & $\begin{array}{c}3 .(18)+1.22 \\
(3.54)\end{array}$ & $\begin{array}{c}3.1(0-4.24) \\
(3.53)\end{array}$ & $\begin{array}{c}3.12-4.20 \\
(3.54)\end{array}$ \\
\hline
\end{tabular}

"Figures within parentheses indicate the mean values

"Analysed by TAA.

Analysed hy MKJ.

and those prepared by using mercury were analysed by MKJ as above. The latter could not be analysed by TAA in view of the significant interference in the colorimetric estimation caused by the precipitation of mercury ions.'

The effect of gradually adding $\mathrm{H}_{2} \mathrm{O}_{2}$ during digestion was also studied. Initially, $1 \mathrm{ml} \mathrm{of} \mathrm{H}_{2} \mathrm{O}_{2}$ was added, and the remainder drop by drop using a Pasteur pipette. The additions were trickled down the side of the digestion tube to control effervescence during digestion. The efficiency of digestion was also studied by adding $1,2,3$, or $4 \mathrm{ml} \mathrm{H}_{2} \mathrm{O}_{2}$ to the flasks before digestion. Nitrogen recoveries were measured by adding ammonium sulphate and sodium nitrate (equivalent to $0.5-1.6 \mathrm{mg} \mathrm{N}$ ) to the sample before the digestion.

Total $\mathrm{N}$ was also determined after adding salicylic acid. as a reducing agent, to include nitrate- $\mathrm{N}$ in the tissue. $\mathrm{H}_{2} \mathrm{SO}_{4}(3 \mathrm{ml})$ containing $5 \%$ (by vol) salicylic acid was added to a weighed sample by using a procedure described earlier. ${ }^{4}$ Salicylic acid was tested using $\mathrm{H}_{2} \mathrm{O}_{2}$ digestion and catalyst digestion.

\section{Results and discussion}

\subsection{Comparison of $\mathrm{H}_{2} \mathrm{O}_{2}$ digestion and catalyst digestion procedures}

Accuracy and precision are important considerations for any method used for routine analysis. To assess the accuracy of the $\mathrm{H}_{2} \mathrm{O}_{2}$ digestion procedure, samples of leaf. stem and seed of chickpea and pigeonpea were analysed by all three methods for $\mathrm{N}$ content: the results are presented in Table 1 . A comparison of the two digestion procedures did not reveal large differences in the mean $N$ values of leaf and grain samples of both chickpea and pigeonpea. However, the mean $\mathrm{N}$ values for stem samples were higher for both catalyst digests than with the $\mathrm{H}_{2} \mathrm{O}_{2}$ digest, even after adding slightly larger amounts of $\mathrm{H}_{2} \mathrm{O}_{2}$. It may be that the stem tissue being fibrous and woody in nature was not digested properly without the catalyst. However. addition of larger volumes of sulphuric acid ( $5 \mathrm{ml})$ and $\mathrm{H}_{2} \mathrm{O}_{2}(5 \mathrm{ml})$ did not improve the $\mathrm{N}$ recovered in $\mathrm{H}_{2} \mathrm{O}_{2}$ digests of stem tissues (results not shown).

Further, the functional relationships between $\mathrm{H}_{2} \mathrm{O}_{2}$ digestion and catalyst digestions were worked out according to the procedure described earlier. ${ }^{15}$ It was observed that, with two exceptions, intercept and slope between the methods did not differ significantly $(P \leqslant 0.05)$ from zero and unity. respectively, when comparisons between $\mathrm{Hg}$ catalyst and $\mathrm{H}_{2} \mathrm{O}_{2}$ digestion, and between Se catalyst 
Table 2. Coefficients of functional linear relationships hetween $\mathrm{H}_{2} \mathrm{O}$, digestion and cattalyst digestion for chickped and pigeonpea $\operatorname{sic} \sin ^{2}$

\begin{tabular}{|c|c|c|c|c|}
\hline \multirow[b]{2}{*}{ Tissuc } & \multicolumn{2}{|c|}{ Chickpeil } & \multicolumn{2}{|c|}{ Pigcounpeca } \\
\hline & Intercept & Slope & Intcricent & Slope \\
\hline \multicolumn{5}{|c|}{$\mathrm{H}_{2} \mathrm{O}$, digestuón is $\mathrm{Hg}$ cattalys } \\
\hline Leaf & $\begin{array}{c}0 .(k) \\
(\cdots 0.24 .0 .11)\end{array}$ & $\begin{array}{c}101 \\
(11.96 .1 .(5))\end{array}$ & $\begin{array}{c}11+3 \\
(-1)(1) 2 .(1) \text { s(n) }\end{array}$ & $\begin{array}{c}11 \text { sis } \\
\text { (11.22.1.112) }\end{array}$ \\
\hline Stem & $\begin{array}{c}-0.112 \\
(-0.11,(0.1) 7)\end{array}$ & $\begin{array}{c}1.01 \\
(10.94 .1 .(19))\end{array}$ & $\begin{array}{c}10.114 \\
(-11.11 .11(x))\end{array}$ & $\begin{array}{c}1145 \\
\text { (1) } 43.1 .111)\end{array}$ \\
\hline Seed & $\begin{array}{c}-1) .16 \\
(-11.4(1), 11 .(18)\end{array}$ & $\begin{array}{c}1.03 \\
(0.45 .1 .10)\end{array}$ & $\begin{array}{c}-1)(k) \\
(-11.12 .(1)(k) 2)\end{array}$ & $\begin{array}{c}1.01 \\
(11.07 .1 .11 .3)\end{array}$ \\
\hline \multicolumn{5}{|c|}{$\mathrm{H}_{2} \mathrm{O}_{2}$ digestion is Se catalyst } \\
\hline Leaf & $\begin{array}{c}-10.13 \\
(-1) 25.0 .112)\end{array}$ & $\begin{array}{c}1.112 \\
(1.98 .1 .(17)\end{array}$ & $\begin{array}{c}0.11 .3 \\
(-11.25,(1 . .34)\end{array}$ & $\begin{array}{c}0.94 \\
\text { (11.89. } 1 \text { (k)) }\end{array}$ \\
\hline Stem & $\begin{array}{c}-11.112 \\
(-0.05 .011 .(159)\end{array}$ & $\begin{array}{c}-11.96 \\
(10.41 .1 .113)\end{array}$ & $\begin{array}{c}11.112 \\
(-11.115 .01(104)\end{array}$ & $\begin{array}{c}11.9 \mathrm{~S} \\
\left(11.41 .1 .\left(k_{1}\right)\right.\end{array}$ \\
\hline Seced & $\begin{array}{c}0.21 \\
(-0.4(1)-(1.01)\end{array}$ & $\begin{array}{c}1.144 \\
(11.49,1.1(1)\end{array}$ & 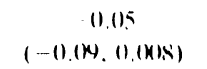 & $\begin{array}{c}1.01 \\
(11.49 .1 .112)\end{array}$ \\
\hline
\end{tabular}

"Both $\mathrm{H}_{2} \mathrm{O}$ : digests and selenium digests were analysed by TAA: mercury digests were anallsed by . Nh.l.

Values within parentheses are the $95 \%$ confidence limits.

and $\mathrm{H}_{2} \mathrm{O}_{2}$ digestion were made ( $\Gamma$ able 2). The exceptions were with chickpea seed $\left(\mathrm{H}_{2} \mathrm{O}_{2}\right.$ digestion versus Se catalyst) and pigeonpea seed ( $\mathrm{H}_{2} \mathrm{O}_{2}$ digestion versus $\mathrm{Hg}$ catalyst). However, in these iwo instances the methods compared do not show highly significant differences at the $P \leqslant(1.11$ level in respect of intercept and slope from zero and unity. respectively. This indicated that the digestion procedures examined did not produce results which differed signficantly from each other. Correlation coefficients between $\mathrm{H}_{2} \mathrm{O}_{2}$ digestion and catalyst digestion procedures for different plant tissues are given in Table 3. Highly significant correlations were observed for both chickpea and pigeonpea. However, correlations were lower for stem tissue than with leaf and seed samples. It appears that the $\mathrm{H}_{2} \mathrm{O}_{2}$ digestion procedure for the determination of $\mathrm{N}$ in stem samples is less accurate than for leaf and seed samples. But the correlations are reasonable enough to suggest that this procedure may be used where a large number of stem samples are to be analysed routinely. There were highly significant correlations between TAA and MKJ methods for leaf, stem and grain samples of both chickpea and pigeonpea. This confirms earlier findings, ${ }^{3.4}$ and further suggests that a rapid procedure of TAA could be used for $\mathrm{N}$ analysis of leaf and stem samples. although additional studies are required to test its suitability for a large-scale $N$ determination in these tissues.

Table 3. Correlation coefficients hetween $\mathrm{N}$ values obtained by $\mathrm{H}_{2} \mathrm{O}$, - digestion and catalyst-digestion procedures

\begin{tabular}{cccc}
\hline & \multicolumn{4}{c}{ Corrclation cocficicnt" } \\
Tissuc & a & $h$ & $c$ \\
Chickpea: I.caf $(n=40)$ & & & \\
Stem $(n=35)$ & 0.98 & 0.97 & 0.99 \\
Seed $(n=60))$ & 0.84 & 0.85 & 0.97 \\
Pigeonpea: Leaf $(n=40)$ & 0.99 & 0.96 & 0.98 \\
Stem $(n=35)$ & 0.93 & 0.94 & 0.97 \\
Seed $(n=60)$ & 0.83 & 0.82 & 0.95 \\
& 0.98 & 0.97 & 0.96 \\
\hline
\end{tabular}

${ }^{a} \mathrm{H}_{2} \mathrm{O}_{2}$ digestion TAA $(x)$ is $\mathrm{Se}$ digestion (TAA) $(y)$.

${ }^{b} \mathrm{H}_{2} \mathrm{O}_{2}$ digestion TAA $(x)$ is $\mathrm{Hg}$ digestion (MKJ) (l).

'Se digestion TAA $(x)$ vs $\mathrm{Hg}$ digestion (MKJ) $(y)$.

"Significant at $1 \%$ level. 
Table 4. Standard error of estimation of nitrogen in chickpea samples by different procedures"

\begin{tabular}{|c|c|c|c|c|c|}
\hline & \multirow[b]{2}{*}{ Tissue } & \multicolumn{2}{|c|}{$\mathrm{H}_{2} \mathrm{O}_{2}$-digestion } & \multicolumn{2}{|c|}{ Catalyst-digestion } \\
\hline & & TAA & MKJ & $\mathrm{TAA}^{b}$ & MKJ' \\
\hline \multirow[t]{3}{*}{ Leaf } & Range & $2.9 x-3.10$ & $3.07-3.14$ & $3.01-3.12$ & $3.02-3.14$ \\
\hline & Mcan & 3.04 & 3.10 & 3.115 & 3.08 \\
\hline & s.c. \pm & 0.084 & 0.078 & 0.091 & 0.082 \\
\hline \multirow[t]{3}{*}{ Stem } & Range & $1.07-1.12$ & $1.08-1.14$ & $1.12 \cdot 1.18$ & $1.16-1.21$ \\
\hline & Mean & 1.10 & 1.12 & 1.15 & 1.18 \\
\hline & s.c. \pm & 0.1138 & 0.0 .36 & 0.039 & 0.035 \\
\hline \multirow[t]{3}{*}{ Secd } & Range & $3.48-3.54$ & $3.52-3.61$ & $3.47-3.58$ & $3.48-3.55$ \\
\hline & Mean & 3.54 & 3.59 & 3.53 & 3.52 \\
\hline & s.c. \pm & 0.074 & 0.065 & 0.073 & 0.066 \\
\hline
\end{tabular}

"Analysis of 10 independent determinations on a bulk sample.

${ }^{\text {h }}$ Se catalyst digests analysed by TAA.

"Hg catalyst digests analysed by MKJ.

The standard error of determination for the $\mathrm{H}_{2} \mathrm{O}_{2}$ digestion procedure was calculated and compared with that of the standard catalyst digestion procedures. In order to confirm these results, both the TAA and MKJ methods were used for $\mathrm{N}$ determination. It was found that the error involved in both the digestion procedures did not differ greatly from each other when tested by either of the methods of $\mathrm{N}$ determination using chickpea samples (Table 4). A slightly higher error was obtained when both the digests were analysed by the TAA method indicating that the MKJ method is more accurate than TAA procedure. ${ }^{3} \mathrm{~A}$ similar difference was observed when the plant tissue and grain samples of pigeonpea were examined by different procedures.

\subsection{Effect of different concentrations of $\mathrm{H}_{2} \mathrm{O}_{2}$ on $\mathrm{N}$ determination}

Preliminary work was carried out to find the optimum volume of $\mathrm{H}_{2} \mathrm{O}_{2}$ needed for digestion. Table 5 shows the effect of adding different amounts of $\mathrm{H}_{2} \mathrm{O}_{2}$ on the determination of $\mathrm{N}$. No measurable differences in $\mathrm{N}$ values were observed when more than $2 \mathrm{ml} \mathrm{H}_{2} \mathrm{O}_{2}$ was added to leaf or seed samples of chickpea and pigeonpea. However, with stem tissue increasing the volume of $\mathrm{H}_{2} \mathrm{O}_{2}$ up to $3 \mathrm{ml}$ gave higher results. Such a response might perhaps be expected because of the fibrous nature of the stem tissue requiring more $\mathrm{H}_{2} \mathrm{O}_{2}$ for carbonisation. The use of $2 \mathrm{ml} \mathrm{H}_{2} \mathrm{O}_{2}$ for leaf and grain samples and $3 \mathrm{ml}$ for stem tissues was found satisfactory: $\mathrm{H}_{2} \mathrm{O}_{2}$ was added at the beginning of digestion.

Table 5. Effect of different amounts of $\mathrm{H}_{2} \mathrm{O}_{2}$ on digestion and determination of $\mathrm{N}$ in leaf, stem and seed samples"

\begin{tabular}{|c|c|c|c|c|}
\hline \multirow[b]{3}{*}{ Tissuc } & \multicolumn{4}{|c|}{ Nitrogen content ( $\%$ ) } \\
\hline & \multicolumn{4}{|c|}{ Amount of $\mathrm{H}_{2} \mathrm{O}_{2}(\mathrm{ml})$} \\
\hline & 1 & 2 & 3 & \\
\hline Chickpea: Leaf & $3.04 \pm 0.07$ & $3.10 \pm 0.07$ & $3.11 \pm 0.06$ & $3.10 \pm 0.07$ \\
\hline Stcm & $1.18 \pm 0.03$ & $1.28 \pm 0.04$ & $1.34 \pm 0.04$ & $1.35 \pm 0.03$ \\
\hline Seed & $3.46 \pm 0.08$ & $3.52 \pm 0.07$ & $3.52 \pm 0.08$ & $3.51 \pm 0.06$ \\
\hline Pigeonpea: Leaf & $3.12 \pm 0.06$ & $3.18 \pm 0.05$ & $3.20 \pm 0.06$ & $3.21 \pm 0.07$ \\
\hline Stem & $0.78 \pm 0.02$ & $0.82 \pm 0.03$ & $0.84 \pm 0.03$ & $0.84 \pm 0.04$ \\
\hline Secd & $3.02 \pm 0.05$ & $3.03 \pm 0.07$ & $3.03 \pm 0.05$ & $3.04 \pm 0.07$ \\
\hline
\end{tabular}

aAnalysed by TAA. Mean of three determinations. 
Table 6. Effect of the method of addition of $\mathrm{H}_{2} \mathrm{O}_{2}$ on $\mathrm{N}$ values ${ }^{a}$

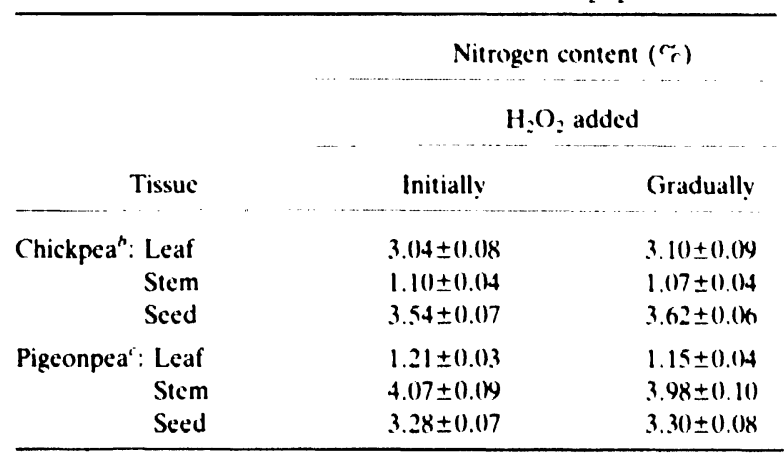

" $\mathrm{H}_{2} \mathrm{O}_{2}$ digests analysed hy TAA.

${ }^{b}$ Mean of 10 independent determinations.

'Mean of six independent determinations.

\subsection{Effect of the method of addition of $\mathrm{H}_{2} \mathrm{O}_{2}$ on $\mathrm{N}$ determination}

In order to study the effect of the method of adding $\mathrm{H}_{2} \mathrm{O}_{2}, \mathrm{~N}$ was determined on the digests prepared in two ways: (1) the total amount of $\mathrm{H}_{2} \mathrm{O}_{2}$ was added at the beginning of digestion; (2) $\mathrm{H}_{2} \mathrm{O}_{2}$ was added gradually as described carlier. The results obtained on different tissues based on such a comparison are shown in Table 6 . No significant differences in $\mathrm{N}$ values were observed when either the whole amount of $\mathrm{H}_{2} \mathrm{O}_{2}$ was added initially or added gradually as digestion proceeded. Florence and Milner, using a variety of animal and plant products, suggested a gradual drop by drop addition of $\mathrm{H}_{2} \mathrm{O}_{2}$ during the process of digestion, but this procedure ${ }^{12}$ was cumbersome and would limit the number of analyses on a routine basis.

\subsection{Recovery of added $\mathrm{NH}_{4}^{+}-\mathrm{N}$ and $\mathrm{NO}_{3}-\mathrm{N}$}

Recovery of added $\mathrm{NO}_{3}-\mathrm{N}$ was low with either $\mathrm{H}_{2} \mathrm{O}_{2}$ - or catalyst-digestion procedures (Table 7). Small differences in $\mathrm{N}$ recovery values were observed when stem, leaf and seed samples of these crops were compared. Nitrogen recovery values of $\mathrm{NH}_{4}{ }^{+}-\mathrm{N}$ obtained by either digestion procedure was good and did not differ significantly from each other. Because $\mathrm{NO}_{3}-\mathrm{N}$ present in the tissues will not be detected by the procedures described here, an attempt was made to determine the $\mathrm{NO}_{3}-\mathrm{N}_{\text {by }}$ using salicylic acid as a reducing agent in the digestion mixture, but no noticeable differences were found (Table 8). While $\mathrm{NO}_{3}-\mathrm{N}$ is usually absent in seed samples, $\mathrm{NO}_{3}-\mathrm{N}$ ranging from 20 to

Table 7. Recovery (\%) of added $\mathrm{NO}_{3}-\mathrm{N}$ and $\mathrm{NH}_{4}{ }^{+}-\mathrm{N}$ using $\mathrm{H}_{2} \mathrm{O}_{2}-\mathrm{N}$ and catalyst-digestion procedures

\begin{tabular}{|c|c|c|c|c|c|c|}
\hline \multirow[b]{3}{*}{ Tissue } & \multirow{2}{*}{\multicolumn{2}{|c|}{$\mathrm{H}_{2} \mathrm{O}_{2}$ digestion ${ }^{a}$}} & \multicolumn{4}{|c|}{ Catalyst digestion } \\
\hline & & & \multicolumn{2}{|c|}{ Selenium ${ }^{\prime \prime}$} & \multicolumn{2}{|c|}{ Mercury ${ }^{b}$} \\
\hline & $\mathrm{NO}_{3}-\mathrm{N}$ & $\mathrm{NH}_{4}{ }^{+} \cdot \mathrm{N}$ & $\mathrm{NO}_{3}-\mathrm{N}$ & $\mathrm{NH}_{4}{ }^{+} \cdot \mathrm{N}$ & $\mathrm{NO}_{3}-\mathrm{N}$ & $\mathrm{NH}_{4}{ }^{+}-\mathrm{N}$ \\
\hline Chickpea: Leaf & $40.8 \pm 1.2$ & $98.5 \pm 2.1$ & $61.6 \pm 1.4$ & $99.3 \pm 1.9$ & $59.4 \pm 1.8$ & $98.7 \pm 2.1$ \\
\hline Stem & $40.4 \pm 1.5$ & $100.4 \pm 1.9$ & $56.2 \pm 1.5$ & $98.4 \pm 2.0$ & $57.5 \pm 1.9$ & $99.0 \pm 1.6$ \\
\hline Seed & $39.3 \pm 1.5$ & $97.8 \pm 1.8$ & $64.3 \pm 1.8$ & $97.4 \pm 1.7$ & $63.6 \pm 2.0$ & $96.5 \pm 2.0$ \\
\hline Pigeonpea: Leaf & $64.0 \pm 1.8$ & $96.5 \pm 2.0$ & $63.5 \pm 1.9$ & $99.0 \pm 1.8$ & $64.8 \pm 1.3$ & $96.4 \pm 2.5$ \\
\hline Stem & $40.5 \pm 1.4$ & $98.9 \pm 1.9$ & $53.8 \pm 1.7$ & $98.2 \pm 2.2$ & $55.6 \pm 1.9$ & $97.5 \pm 1.8$ \\
\hline Seed & $36.4 \pm 1.7$ & $98.7 \pm 2.1$ & $50.8 \pm 2.9$ & $99.8 \pm 1.9$ & $52.9 \pm 1.4$ & $98.3 \pm 2.0$ \\
\hline
\end{tabular}

${ }^{a} \mathrm{H}_{2} \mathrm{O}_{2}$ digests and $\mathrm{Se}$ catalyst digests analysed by TAA.

${ }^{b} \mathrm{Hg}$ catalyst digests analysed by MKJ.

'Mean of three determinations. 
Table 8. Comparison of $H_{2}, O_{2}$. catalyst. and catalyst + salıcylic acid digestion procedures for total $\mathrm{X}$ determination.

$$
\text { Nitrogen content ('i) }
$$

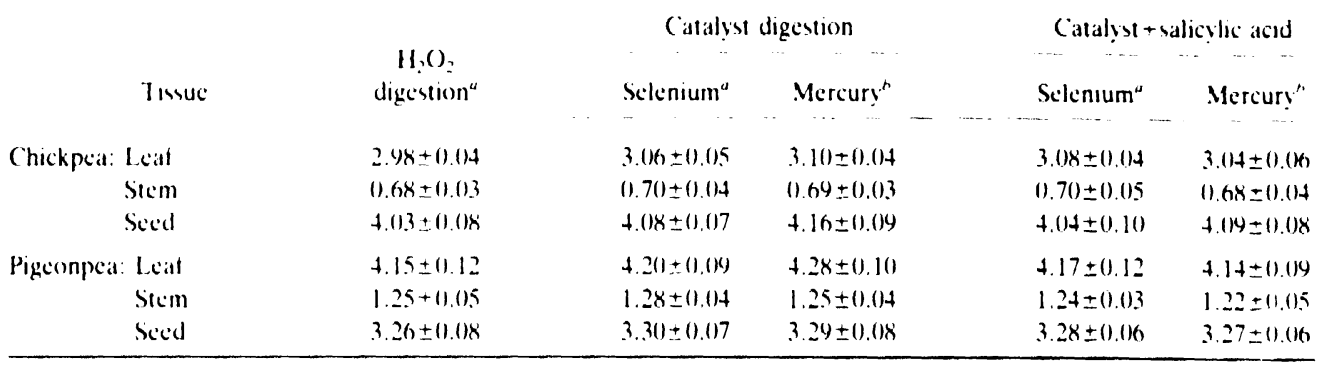

"H,O, digests and Se cataly'st digests analysed by TAA

"Ilg cattalyst digests analysced hy MKJ.

'Mean of threc determinations.

$200 \mu \mathrm{gg}^{-1}$ has been found in leaf and stem samples of these crops (unpublished results). These levels are not large enough to cause significant errors against a background organic $\mathrm{N}$ content of $2-4 \mathrm{C}^{\prime} \mathrm{c}$

\section{Conclusion}

The results presented here using diverse plant samples indicate that the $\mathrm{H}_{2} \mathrm{O}_{2}$-digestion method can easily be adapted for total $\mathrm{N}$ analyses using either the auto-analyser or distillation techniques.

\section{Acknowledgement}

The authors thank S. R. Rahman and G. L. Waghray for technical assistance and Drs Jagdish Kumar and N. P. Saxena for the supply of seed. stem and leaf samples.

\section{References}

1. Bradstrect. R. B. The Kjeldahl Method of Organic Nitrogen Academic Press. 1965

2. Mitcheson. R. C.: Stowell. K. C. Technicon international symposium. In: Automation in Analyzical Chemistry. Charles Burrel \& Son. (hertsey, 1969. pp. 197-210.

3. Singh. U: Jambunathan. R. Evaluation of rapid methods for the estimation of protein in chickpea ( (Cicer arietinum L.).J Sci. Food Agric. 1980, 31, 247-254.

4. Singh. U: Jambunathan. R. Methods for the estimation of protcin in pigeonpea (Cajames cajan I..) and relationship betucen grain and dhal protein contents. J. Sit. Food Agric. 1981. 32, 7015-710.

5. Williams. P. C. The use of titanium dioxide as a catalyst for large scale Kjeldathl determination of the total nitrogen content of cereal grains. J. Sci. Food Agric. 1973, 24, 343-348.

6. Klopper. W. J. The use of titanium dioxide as a catalyst for the Kjeldahl determination of the total nitrogen content of barley. malt and beer. Bratunisienschaft 1976. 29, 231-233.

7. Smith. R. E.: Correa. A.: Vargas. A. M. (omparison of mercury and selenium catalysts for determination of Kjeldahl-N in leaf and stem tissues of pigeonpea (Cajamus cujan Millsp.). Trop. Grain Legume Bull. 1978. 11, 26-28.

8. Wall, I.. L.: Gichrke. C. W.: Neuner. T. E.: Cathey. R. D.: Rexford, P. R. Total protein nitrogen: Evaluation and comparison of four different methods. J. Assoc. Off. Anal. Chem. 1974, 58, 811-817.

9. Yuen. S. H. Ph.D. Thesis. University of London. 1948.

10. Yuen. S. H.: Pollard. A. (. Determination of nitrogen in Agricultural materials by the Nessler reagent. Il. Micro-determination in plant tissue and soil extracts. J. Sci. Food Agric. 1954. 5, 36t-369.

11. Ekpetc. D. M.: Cornficld. A. H. Comparison of Kjeldahl and sulphuric acid-hyddrogen perioxide methods and their salicylic acid-thiosulphate modifications for determining total nitrogen in grasses. Analyst 1964. 89, 670-673.

12. Florence. E.: Milner. D. K. Routine determination of nitrogen by Kjeldahl digestion without use of catalyst. Analyst 1979. 104, 378-.381.

13. Official Methods of Analisis Association of Official Analytical Chemists. Washington. DC. 1975. 12th edn

14. Eastin. E. F. Total nitrogen determination for plant material containing nitrate. Anal. Biochem. 1977. 85, 591-594.

15. Kendall. M. G.: Stuart. A. Structural and functional relationships. In: The Advanced Theorn of Statistics Vol 2. Charles Griffin \& Comp Ltd. London. 1979. p. 298. 